\title{
The current treatment of fibromyalgia
}

\author{
O tratamento atual da fibromialgia
}

José Oswaldo de Oliveira Júnior ${ }^{1}$, Mauro Brito de Almeida²

DOI 10.5935/2595-0118.20180049

\section{ABSTRACT}

BACKGROUND AND OBJECTIVES: Fibromyalgia is a highly relevant theme for research considering its impressive $2 \%$ worldwide prevalence, diffuse pain and suffering, largely unknown pathophysiology, scarce odds of cure and, more often than not, poor symptom control. This study aims to review the main options of treatment for fibromyalgia, including some novel alternatives.

CONTENTS: The pharmacological treatment for fibromyalgia can be prescribed in monotherapy or combination of drugs, which comprises antidepressants, muscle relaxants, anticonvulsants, cannabinoids, opioids, N-methyl D-Aspartate antagonists, melatoninergic agonists, peptidergic substances among others. Non-pharmacological therapies include acupuncture, behavioral (or psychobehavioral) and psychological (or psychotherapy) interventions, physical activity programs, hyperbaric oxygen therapy, ozone therapy, transcranial magnetic stimulation, stretching exercises associated to low intravenous curare doses, among others. Treatment modalities are presented according to possible mechanisms of action, level of scientific evidence and recommendation.

CONCLUSION: Fibromyalgia therapy should be individualized, and it does not aim the cure. Its objective is to reduce the subject's suffering; provide function improvement and, as much as possible, the individual's autonomy and quality of life. There is much in common in most approach recommendations, yet there are some divergence and changes as knowledge is acquired about a theme where consensus is far from being achieved.

Keywords: Amytriptiline, Behavioral therapy, Duloxetine, Fibromyalgia, Physical activity programs, Pregabalin, Treatment.

1. Hospital A C Camargo, São Paulo, SP, Brasil.

2. Hospital Ophir Loyola, Belém, PA, Brasil.

Submitted in May 23, 2018.

Accepted for publication on July 18, 2018.

Conflict of interests: none - Sponsoring sources: none.

Correspondence to:

José Oswaldo de Oliveira Júnior

E-mail: jo.oliveirajr@yahoo.com.br

(C) Sociedade Brasileira para o Estudo da Dor

\section{RESUMO}

JUSTIFICATIVA E OBJETIVOS: A impressionante prevalência de $2 \%$ da fibromialgia na populaçáo mundial, associada ao sofrimento a ela atribuída, à sua fisiopatologia ainda não integralmente desvendada, ao prognóstico reservado em relação à possibilidade de cura, e, aos resultados insatisfatórios no controle de seus sintomas, mormente os dolorosos; fazem dela um tema preferencial para investigação e estudo. O objetivo deste estudo foi apresentar uma revisáo sobre os principais tratamentos sugeridos para os portadores de fibromialgia, incluindo alguns emergentes.

CONTEÚDO: O tratamento farmacológico da fibromialgia pode ser aplicado em monoterapia ou combinar fármacos, inclusive antidepressivos, relaxantes musculares, anticonvulsivantes, canabinoides, opioides, antagonistas N-metil D-Aspartato, agonistas melatoninérgicos, substâncias peptidérgicas entre outras. Os tratamentos classificados como não farmacológicos incluem a acupuntura, intervençóes comportamentais (ou psicocomportamentais), psicológicas (ou psicoterápicas), programas de atividade física, oxigenoterapia hiperbárica, ozonioterapia, estimulação magnética transcraniana, relaxamento muscular com baixas doses de curare por via venosa associado a alongamento e realongamento, entre outros. Os tratamentos são apresentados e situados em relação aos respectivos possíveis mecanismos de ação, evidência científica e graus de recomendação.

CONCLUSÃO: O tratamento da fibromialgia é individualizado, e, não propóe sua cura. O objetivo é a redução do sofrimento de seus portadores, a melhora da funcionalidade, e na medida do possível, da autonomia pessoal e da qualidade de vida. A maioria das condutas e recomendaçóes possuem muito em comum, porém não são totalmente congruentes, mostram dinamismo e mudanças à medida em que se acumula conhecimento sobre um assunto sobre o qual o consenso ainda está muito longe de ocorrer. Descritores: Amitriptilina, Duloxetina, Fibromialgia, Pregabalina, Programas de atividade física, Terapia psicocomportamental, Tratamento.

\section{INTRODUCTION}

Fibromyalgia (FM) is an idiopathic syndrome, that is, of unknown etiology. Its main characteristic is a chronic generalized pain. Its population distribution is predominantly female.

FM pain is not due to an increase in painful stimulation detected. It is also not secondary to a lesion or disease that affects the somatic-sensory nervous system and is therefore classified as a type of dysfunctional pain. It appears to be associated with central nervous system (CNS) dysfunction that confers an insufficiency of pain suppressive mechanisms. 
Even before the consecration of FM by the American Society of Rheumatology in 1990, Goldenberg ${ }^{1}$ already established that the diagnosis of this condition, then emergent and until now controversial condition, would be made by excluding other syndromes that evolve with diffuse pain.

Today FM is considered a fairly frequent condition (average prevalence of $2 \%$ in the general world population), expensive and, above all, still controversial ${ }^{2}$.

The best treatment for any pain is the one that owes its cause ${ }^{3}$. In the case of FM, its cryptogenic or primary condition prevents the desirable etiological treatment.

Symptoms include pain (spontaneous, diffuse concomitant and/ or itinerant, presence of hyperalgesia and/or allodynia, modified by emotional condition), reduced strength and/or muscle performance, fatigue, stiffness, high stress, depression, anxiety, excessive vigilance, attention deficit disorder, non-restorative sleep, among others.

The syndromic character of FM, whose clinical manifestations have no known cause, but rather the implication of several factors in its pathophysiology, results in the absence of objective diagnostic tests and specific treatment.

Incomplete understanding of the pathophysiology of FM urges the adoption of options focused on symptom management and control to improve the function and quality of life $(\mathrm{QoL})$ of its patients and not on the underlying causes ${ }^{4-6}$.

The accumulated knowledge about this disease allowed the development of therapeutic strategies of multidisciplinary and multi-professional application, although, still, they remain unsatisfactory.

\section{PHARMACOLOGICAL INTERVENTIONS}

Pharmacological treatment remains a common element in most cases of $\mathrm{FM}^{7}$. Several drugs have already been used to control FM symptoms. Antidepressants are probably the most commonly used in maintenance treatment. Among tricyclics, amitriptyline is the drug that gathers more information in the literature, inhibits the reuptake of both norepinephrine and serotonin, which in descending modulating systems generates central analgesia. Its level of recommendation between guidelines is high, with a tendency to target doses below $50 \mathrm{mg} /$ day with improvement not only of pain but also of fatigue and sleep $^{8}$. The adverse reaction profile, including weight gain, exaggerated drowsiness and possible changes in consciousness content, especially in the elderly, tend to be the major obstacles to the regular use of amitriptyline since it has a low cost and convenient dosage.

Cyclobenzaprine has a structure similar to amitriptyline, which also classifies it as tricyclic. However, it is not known to have antidepressant effects ${ }^{9}$. It is available in countries such as the United States, Canada, and Brazil, but not in others like the United Kingdom. Cyclobenzaprine was initially released as an antipsychotic drug; and, currently, its most frequent prescription has an indication of a central action muscle relaxant. A meta-analysis of the use of this drug in patients with FM reported that it leads to symptomatic improvement in one in five patients ${ }^{10}$. The adverse reactions commonly associated with the use of cyclobenzaprine are similar to those of amitriptyline. Doses of 1 to $4 \mathrm{mg}$ in the evening demonstrated improvement in sleep ${ }^{8}$.

Amitriptyline and cyclobenzaprine are recommended for the treatment of FM in the 2016 guidelines of the European League Against Rheumatism (EULAR) ${ }^{11}$ and the Canadian Pain Society (CPS) ${ }^{8}$, of 2013.

Norepinephrine and serotonin reuptake inhibitors, also known as dual inhibitors, similar to tricyclics, produce central analgesia by action on descending inhibitory nerve pathways. In general, they present better tolerability and adverse reaction profile than tricyclics.

Duloxetine is the drug in this group that has the best evidence of efficacy for the treatment of FM, usually at a dose of $60 \mathrm{mg} /$ day, especially when there is associated depressive morbidity, accompanied or not by anxiety ${ }^{12}$.

Although there are signs of serotonin participation in the pathophysiology of FM, even though its reuptake is a common factor of at least part of the action of the classes of antidepressants already described, selective serotonin reuptake inhibitors, widely used in the recent treatment of FM, do not find support for the control of symptoms of the syndrome in current guidelines ${ }^{13,14}$. They present similar efficacy to placebo; however, they can be used to treat associated psychiatric morbidity, in the context of $\mathrm{FM}^{8}$.

In addition to duloxetine, another dual antidepressant, milnacipran, a selective serotonin and norepinephrine reuptake inhibitor, also contributes to the treatment of fibromyalgic patients with reduced fatigue and depressive symptoms ${ }^{15-17}$. Milnacipran was considered useful in patients who also complained of cognitive difficulties ${ }^{18,19}$. The mixed effects of duals in patients suffering from FM are consistent with their pharmacological differences which include the superior noradrenergic effect of milnacipran over duloxetine. Another difference between these two duals resides in the metabolism, which in duloxetine depends on the cytochrome P450 2D6 pathway, as well as a portion close to $25 \%$ of other drugs commonly used in clinical practice, conferring a good chance of interaction. Such pharmacological interaction is aggravated by possible genetic variations and their cytochrome polymorphisms. Milnacipran is not metabolized by this pathway. Its metabolism is more predictable and with less possibility of interaction ${ }^{20}$.

Although both drugs have a good profile regarding their adverse reactions, important differences can be experienced by patients with $\mathrm{FM}^{21,22}$.

Among the anticonvulsants, pregabalin and gabapentin are the most commonly used. Although both have structural similarity with the gamma-aminobutyric acid neurotransmitter (GABA), they have no action in this pathway, but in voltage-dependent calcium channels ${ }^{7,23}$. These anticonvulsants bind to the alpha2-delta subunits of calcium channels. However, it remains unknown how they act precisely to benefit the clinical manifestations in $\mathrm{FM}^{23}$.

The most accepted current postulate suggests that in this syndrome there would be glutamatergic hyperactivity which, in turn, would be controlled by blocking calcium influx at presyn- 
aptic terminals by pregabalin action ${ }^{26}$. In the treatment of FM, there is variability in the literature regarding the recommendations of these drugs. Cooper et al. ${ }^{27}$ considered scarce the evidence of the benefit of gabapentin at doses between 1200 and $2400 \mathrm{mg} /$ day in antalgic therapy for FM compared to placebo, although the majority of patients reported a sensation of overall improvement. While there is evidence of improvement in pain, sleep, and general activities when patients with FM use pregabalin at daily doses of $300-600 \mathrm{mg} /$ day, which were significantly higher than those receiving placebo ${ }^{7,23-25}$.

Both gabapentinoid drugs are usually well tolerated, dizziness and drowsiness are usually the most commonly reported adverse reaction ${ }^{23,27}$. When compared, pregabalin has three to four times faster absorption and greater bioavailability ${ }^{28,29}$.

Gabapentin presents a saturation absorption situation, which does not occur with pregabalin that presents linear kinetics ${ }^{29}$. Administration of pregabalin is more convenient, requiring longer time intervals between doses; their doses are lower than those of gabapentin and are therefore associated with fewer adverse reactions ${ }^{29-32}$. When the analgesic effect is analyzed, the result of the use of pregabalin is more intense than that of gabapentin $^{29,33,34}$. Unlike gabapentin, whose indication for relieving fibromyalgic symptoms has always been out of the package insert, as of mid-2007, levels of scientific evidence have allowed pregabalin to be the first approved drug for the treatment of patients with FM in the United States of America ${ }^{35}$.

Although the action in descending inhibitory pathways is decisive in the efficacy of the pharmacological treatment of FM, interestingly opioids, in general, do not have good efficacy in the treatment of this syndrome. This can be explained, at least in part, by the low opioid activity and the paucity of mu receptors in descending modulating nociceptive pathways in patients with the disease ${ }^{36,37}$.

Inhibition of facilitator systems and/or enhancement of pain-facilitating systems are frequently and repeatedly reported in patients complaining of persistent pain in which central sensitization occurs, such as those with FM. However, the exact effects of frequently prescribed opioids on central pain modulation are still unknown ${ }^{38}$.

Increased endogenous opioid activity has been observed in the CNS of patients with FM and may in some way be related to a form of opioid-induced hyperalgesia ${ }^{39}$. The use of an opioid receptor antagonist such as naltrexone to block the release of endogenous opioids has been proposed as an effective treatment strategy in fibromyalgic patients ${ }^{40}$. In a double-blind, randomized, placebo-controlled study in patients with FM, naltrexone at a low dose $(4.5 \mathrm{mg} / \mathrm{d})$ reduced pain and improved mood but did not alter fatigue and sleep disturbance ${ }^{40}$.

The beneficial effects observed with low doses of naltrexone in fibromyalgic patients have been explained by the involvement of the antagonism to microglia, besides blocking the release of endogenous opioids. Proliferative factors released into the CNS by microglia, which appear to be abnormally sensitized in FM, can lead to central facilitation of pain processing ${ }^{31}$. These results are encouraging and promising for the use of low doses of naltrexone as a treatment for FM. However, more studies are needed to identify the value of these mechanisms of action, particularly in relation to glial cells.

A weak opioid, such as tramadol, is more effective than other opioids for FM pain control. Possibly because it has amine reuptake inhibition activity besides being mu agonist ${ }^{7,42}$. Guidelines for the treatment of this condition recommend the use of this analgesic. However it is important to consider the tolerance and tachyphylaxis commonly associated with its prolonged use $e^{8,14}$.

Non-hormonal anti-inflammatories have a very low indication in $\mathrm{FM}^{33}$. They may have some utility, preferably in low doses and for short periods, in associated rheumatological conditions ${ }^{8}$. Common analgesics also have no recommended use for $\mathrm{FM}^{43}$. However, some studies, such as acetaminophen, have shown signs of central action, including in the endogenous cannabinoid system ${ }^{44}$. Drugs with this property have recently gained interest in its potential for improved sleep, pain, and appetite. Some guidelines suggest the possibility of its use in case of concomitant dyssomnia ${ }^{8}$. Others do not recommend it, pointing out the need for more in-depth research on the subject and concern about the risk of abuse ${ }^{14}$.

Cannabinoids have been proposed as useful drugs in the treatment of fibromyalgia syndrome by their involvement in the regulation of pain processing and chronic stress. Two cannabinoids, nabilone (at a dose of 0.5 to $1.0 \mathrm{mg} /$ day) and dronabinol (a synthetic form of delta-9-tetrahydrocannabinol or THC at a dose of $7.5 \mathrm{mg} /$ day) significantly reduced pain levels, depression and anxiety in patients with FM, providing them with significant improvement in $\mathrm{QoL}^{45-47}$.

The incidence of adverse reactions and dropout rates of up to $25 \%$ during clinical trials suggest that clinical use of nabilone and dronabinol may be limited ${ }^{45-47}$.

It is believed that hepatic metabolites of the first metabolism of cannabinoids are responsible for the psychotropic effects. Transdermal delivery of the ester of D-glyceric acid of THC, ZYN001, avoids first-pass hepatic metabolism and leads to rapid hydrolysis by the esterases on the skin to $\mathrm{THC}^{48,49}$. The evaluation of the transdermal application of ZYN001 in patients with FM should provide a better tolerability profile for a cannabinoid ${ }^{48,50-52}$.

In FM, levels of the algogenic substance, neurokinin, known as substance $\mathrm{P}$, are elevated in the cerebrospinal fluid ${ }^{39}$. However, when tested, neurokinin receptor antagonists in clinical trials in FM and other chronic pain situations have failed to demonstrate efficacy or provide inconsistent results ${ }^{53}$. The action of capsaicin on the type 1 subunits of vanilloid receptors (TRPV1), located in the peripheral nociceptors, causes the release of substance $P$. This neurokinin is part of a broader set of algogenic and proinflammatory substances secreted by the pseudo unipolar neuron at its two extremities (central peripheral and medullary nociceptor). The initial release corresponds to an increase in discomfort, with a marked increase in neuro mediate (neurogenic) inflammation in the periphery and a presumed increase in CNS sensitization. However, over time, nociceptive processes are desensitized due to the depletion of these substances, including the so-called substance $\mathrm{P}^{54,55}$. 
Depending on the dose and time of exposure, capsaicin may cause from temporary dysfunction, degranulation, hydropic degeneration, hyaline degeneration, to neuronal necrosis; At present, capsaicin is considered a neurotoxicant of fine fibers.

Patients with FM refractory to other treatments show a reduction in the values of pain intensity scales, a significant increase in thresholds for pain stimuli, improvement of mood and fatigue sensation when submitted to topical treatment with capsaicin at concentrations of $0.075 \%$ applied 3 times daily for 6 weeks) ${ }^{56}$. Although the visual analog scale (VAS) of pain intensity was not significantly altered in this study, the impact of the syndrome on the patients, as determined by the FM impact questionnaire, was reduced, leading to a short-term improvement. These results are compatible with the capsaicin-induced modulation in pseudo unipolar neurons that reach from the periphery such as the CNS, modifying the final summation of the activation and inhibition of several of the mechanisms responsible for FM symptoms.

Glutamate N-methyl D-aspartate (NMDA) receptors, particularly those located in the posterior region of the gray matter of the spinal cord, are fundamental in nociceptive transmission and synaptic plasticity and are therefore considered a target for the treatment of neuropathic pain and dysfunctional ${ }^{57}$. In patients suffering from FM, elevated levels of glutamate have been detected in the main areas of brain pain processing, which evolve with significant reduction concomitantly to treatment that attenuates pain ${ }^{58,59}$.

NMDA receptor antagonists such as ketamine, dextromethorphan, and memantine have shown efficacy in patients with FM, which corresponds to an attenuation of increased glutaminergic activity ${ }^{53}$.

Memantine, in a randomized, double-blind, placebo-controlled study, resulted in a significant reduction in pain and improved QoL evaluation, but did not provide benefits against cognitive status and depression in fibromyalgic patients ${ }^{50}$. These patients who received memantine also showed an increase in brain metabolism with a correlation between the impact values of the syndrome on its patients collected by questionnaire and the choline levels in the posterior insula ${ }^{60}$.

In practice, the use of NMDA antagonists, such as memantine, is limited because of the adverse reactions profile of such drugs not well tolerated by fibromyalgic patients. Thus, the anti-NMDA benefits are restricted to only a subset of patients. It is believed that various adverse reactions of NMDA receptor antagonists are secondary to the modification in the physiological function of the NMDA receptor in the $\mathrm{CNS}^{57}$.

The development of specific antagonists of the NMDA receptor subtype (e.g., NR2A, NR2C, NR2D) that maintains physiological function while suppressing the increased activity of the glutamatergic pathways could offer a preferential treatment approach for FM. The therapeutic targets would be the points responsible for the mechanisms that regulate NMDA receptor activity, such as phosphorylation sites and related enzymes, such as interacting kinases (casein kinase 2, Src $\neg \mathrm{NADH}$ dehydrogenase, among others), rather than ionophores, and could offer an alternative approach to improve the therapeutic window ${ }^{57}$.
The expression levels of regulatory mechanisms of NMDA receptor function signal were increased in spinal cord neurons in an FM model in mice, where hyperalgesia was induced by intramuscular injection of acid saline solution ${ }^{59}$. The analgesic effects in this animal model were associated with the reduction of NMDA receptor signaling, a result that may represent a new therapeutic target for $\mathrm{FM}^{61}$. The contribution of NMDA receptor activity to FM symptoms has also been related to the efficacy of gabapentinoid drugs. Treatment with pregabalin decreased glutamatergic activity in the insula of patients with $\mathrm{FM}^{62}$, further supporting the contribution of glutamatergic activity to the pathophysiology of fibromyalgic syndrome symptoms and highlighting modulation as a therapeutic approach of interest.

Melatonin (N-acetyl-5'-methoxytryptamine) and new melatonin analogs exhibited analgesic properties, in addition to regulating sleep consistent with potential use as a therapeutic approach to chronic pain conditions, such as $\mathrm{FM}^{63}$. Pain intensity, number of pain points, quality of sleep, depression and anxiety were significantly improved by melatonin $(3$ or $5 \mathrm{mg}$ at bedtime) in studies with $\mathrm{FM}^{64,65}$.

Studies involving the combination therapy of melatonin and amitriptyline demonstrated superior improvement of symptoms in relation to amitriptyline alone, but not to the isolated treatment of melatonin ${ }^{54}$. Thus, the noradrenergic and serotonergic components of the endogenous descending system of pain modulation seem to be improved by the concomitant stimulation of melatoninergic receptors, suggesting that the abnormality of the melatoninergic system may also play a role in the pathogenesis of FM. To corroborate this theory, agomelatine, a melatonin analog with a melatoninergic receptor antagonist that has antagonist properties of the 5-HT2C receptor of serotonin, has shown relief from painful symptoms, and improved depression and anxiety but failed to improve sleep quality in fibromyalgic patients ${ }^{66,67}$.

\section{NON-PHARMACOLOGICAL INTERVENTIONS}

The complexity of the fibromyalgia syndrome includes psychological, social and biological factors that require a biopsychosocial approach, preferably concomitant, not consecutive ${ }^{68}$. As a consequence, they are often associated with non-pharmacological treatments such as acupuncture, biofeedback, cognitive-behavioral therapies, body-mind therapy, mindfulness therapy, massage, exercise, hydrotherapy, hyperbaric oxygen therapy, ozone therapy, transcranial magnetic stimulation, others. The millenarian technique of acupuncture seems to be more effective for the benefit of an acute pain than for chronic pain, and it can reduce pain intensity in several chronic conditions, including $\mathrm{FM}^{69}$. Acupuncture reduces inflammation, releases endogenous opioids and reduces anxiety. The analgesic effects of acupuncture may be associated with increased adenosine content metabolized by adenosine triphosphate (ATP) that activates $\mathrm{A} 1$ adenosine receptors.

ATP has been well established as an intracellular energy source for many years. The concept of purinergic signaling was introduced in 1972, suggesting that ATP could also act as an 
extracellular signaling agent ${ }^{70}$. However, this concept was rejected for approximately two decades until technological development enabled the cloning and characterization of ATP receptors and their decomposition products in the early 1990s. Thus, from then on, the concept was accepted and purinergic signaling is now considered a rapidly expanding field ${ }^{71}$. Drugs related to purinergic receptors are being developed to treat a variety of diseases and situations of risk (thrombophilia, urinary incontinence, xerostomia, cystic fibrosis, osteoporosis, pain and cancer $)^{72}$. The involvement of purinergic signaling in the beneficial effects of acupuncture fertilized the field and led to an intensification of research on the so-called acupurines ${ }^{73-75}$. In patients with FM, acupuncture offered little improvement in pain and fatigue ${ }^{69}$.

Interventions called behavioral or psycho-behavioral therapies, psychological or psychotherapeutic, are noninvasive methods useful in the treatment of pain. Biofeedback is a psychophysical method, one of the branches of scientific investigation of the body-mind connection, as a vector starting from the body. Psychophysiology is defined as the field of study that examines the relationships between mental activities and physical functions. It is interested in the mental characteristics that affect the body, as well as the experiences of the body information and the changes induced in it by the emotions ${ }^{76}$. Applied Psychophysiology is a discipline that uses this information for practical purposes, especially research into the control of bodily functions and health problems, including mental health. Psychotherapies and body-mind therapies include, in addition to the techniques of biofeedback (already mentioned), mindfulness (in which more psychological processes are accessed and modulated and then approximated with sensitivity and other sensations from the body), relaxation, incorporate strategies to improve psychological and physical well-being ${ }^{76}$.

Psychotherapeutic interventions of the mind-body type and mental predominance were suggested to improve physical functioning, pain and mood. However, due to inconsistency in the planning and design of clinical trials and other types of studies, the quality of evidence still remains $\operatorname{low}^{77}$. Cognitive-behavioral psychotherapies may be beneficial in reducing pain intensity for up to 6 months, improving negative mood, and reducing the inability of patients with FM. Recently, the European guidelines have shown that biofeedback was effective in reducing pain intensity, although all trials were of poor quality. There was no evidence of efficacy regarding fatigue or sleep, and subgroup analysis suggested that any effect was limited to electromyography rather than electroencephalographic biofeedback $^{11,78}$.

Cognitive-behavioral therapies are important in the treatment of chronic pain, and in the case of fibromyalgia syndrome, it is no different. Chronic pain seems to be influenced by learning and memory processes, suggesting that treatment may also be focused on changing these items. Behavioral and cognitive methods, or a combination of them, are especially suited for this purpose because they can specifically modulate changes in brain function or brain chemistry, present in a specific pain condition, while pharmacological treatments act in a more nonspecific way. Operational behavioral training specifically targets situations in which complaints are associated with high levels of pain intensity. The goals of cognitive training are: to decrease pain behaviors in an effort to extinguish pain; to increase activity levels and healthy behaviors related to work, leisure and family; drug reduction and handling; and, to change the behavior of other significant people ${ }^{79}$. The overall goal is to reduce disability by decreasing pain, and increasing behaviors considered healthy. To avoid negative reinforcement learning, the drug is switched from a pain contingent to a fixed time schedule, where the drug is administered at certain times of the day. Improving activity and reducing inactivity and disability will be driven by similar principles. Studies have shown the efficacy of this training in patients with FM, as well as other pain syndromes ${ }^{80-82}$, and is especially effective in reducing pain behaviors. After operative behavioral treatment in FM, a shift from emotional, motivational processing of experimental pain to more sensitive discriminative processing has been reported ${ }^{82}$. There was a close correlation between the training effect and the brain response to experimental pain stimuli.

The cognitive-behavioral model of chronic pain emphasizes the role of cognitive, affective and behavioral factors in the development and maintenance of chronic pain ${ }^{83}$. Cognitive-behavioral training modifies pain and avoids behaviors, cognitions, and emotions to reduce feelings of helplessness and lack of control in order to establish a sense of control over pain. Several techniques are taught to patients to deal with pain episodes, such as cognitive restructuring, coping strategies, and relaxation and imaging techniques. Cognitive-behavioral pain management has been shown to be a very effective treatment for chronic pain, including $\mathrm{FM}^{84}$. Considering that operative treatment especially reduces pain behaviors and also their intensity, cognitive behavioral therapy (CBT) has a special effect on the affective and cognitive aspects of pain ${ }^{81}$. CBT seems to alter encephalic brain processing through altered connections between pain signals, emotions, and cognition, which leads to greater access to executive regions for reevaluation of pain ${ }^{85}$.

The functions recognized as superior cerebral can exert, on the neural network subordinate to them, influences that modify those of greater salience. Painful perception arises through an interaction between sensory input and prior knowledge. Probably, at least two brain areas are necessary for such interaction: the place where afferent signal analysis occurs and the one that applies the relevant prior knowledge. In the human brain, functional images demonstrated in the last decade of the Twentieth century that the selective attention modifies the activity in areas of early visual processing, specifically for the assisted resource. The initial areas of processing are also modified when the prior knowledge allows emerging from a senseless stimulus. Sources of this modification were identified in the parietal and prefrontal cortices. The modification of the initial areas of processing also occurs based on prior knowledge about the predicted sensory effects of the subject's own actions. The activity associated with the mental image resembles that associated with the preparation of the response (for images) and selective attention (for sensitive images), 
suggesting that the mental images reflect the effects of prior knowledge on the areas of sensory processing in the absence of normal orthodromic sensitivity. Lesions in the sensory processing areas may lead to a form of sensory hallucination that seems to arise from the interaction of prior knowledge with random sensory activity. Contraposition to this situation occurs in hallucinations associated with schizophrenia that may arise from a prior knowledge failure about the motor intentions to modify the activity in relevant sensitive areas. When it functions normally, this mechanism allows us to distinguish our own actions from the independent actions of agents in the outside world ${ }^{86}$. Using descending modulating mechanisms that respect a functional hierarchy of submission with neo corticofugal vector, known in English as "top-down" effect. Many patients with FM are physically unconditioned and therefore can obtain from physical activity programs that involve the activation of endogenous analgesic conditions, an increase of the sense of well-being and improvement of $\mathrm{QoL}^{87}$. In aerobic exercise and endurance tests, improvement of training in pain, physical function, and well-being were observed ${ }^{88}$. Terrestrial or aquatic exercises were considered as equally effective, however, in unconditioned patients, the exercise in the aquatic environment can be particularly valuable $e^{88,89}$.

Hyperbaric oxygen therapy and ozone therapy may induce neuroplastic changes, allowing cells remaining after ischemic lesions to return to old functions or to start new ones, allowing the repair of chronically compromised brain functions. They may also change brain metabolism and its glial function to reduce the signs and symptoms of fibromyalgic syndromes associated with abnormal brain activity ${ }^{90-95}$.

A study of a population of patients with FM submitted to hyperbaric oxygen therapy resulted in improvement of all signs and symptoms, with significant changes in pain reduction, improvement in function evaluation and $\mathrm{QoL}^{96}$. While encouraging, favorable publications on both hyperbaric oxygen therapy and ozone therapy are lacking in quality and still insufficient to provide scientific evidence. Both methods require more and better studies to recognize them as an effective treatment for fibromyalgic patients.

There is evidence that transcranial magnetic stimulation is effective in reducing pain intensity in patients with FM, which has led to the use of this treatment approach for at least a decade ${ }^{97}$. However, other studies with the treatment of fibromyalgic patients by transcranial magnetic stimulation have failed to replicate the beneficial results obtained by Hou, Wang and Kang ${ }^{97}$ questioning the routine recommendation of this method ${ }^{98,99}$.

The diffuse pains of patients suffering from FM are attributed predominantly to muscle sources. Low doses of nondepolarizing muscle relaxant drugs (curares) can be used in the preventive treatment of secondary muscular pains to transient spasms of muscular fibers (fasciculations) observed with the depolarizing. The use of reduced-dose of curares, administered in a fractionated way, with monitoring of extrinsic ocular motor function and voluntary swallowing, promoted significant an- algesia in the majority of fibromyalgic patients. The analgesia obtained was prolonged when associated with stretching and realignment of the muscles involved with the most frequent pain complaints ${ }^{100}$.

\section{CONCLUSION}

The treatment of FM is individualized and exclusively symptomatic. The goal is to reduce the suffering of its patients, to improve the functionality, and to the extent possible of personal autonomy and QoL. Most of the behaviors and recommendations adopted and defended by the guidelines published in the last 30 years have much in common. However, they are not totally congruent, they show dynamism and changes as the versions succeed. The results still remain unsatisfactory.

\section{REFERENCES}

1. Goldenberg DL. Fibromyalgia syndrome. An emerging but controversial condition JAMA. 1987;257(20):2782-7.

2. Hauser W, Ablin J, Fitzcharles MA, Littlejohn G, Luciano JV, Usui C, et al. Fibromyalgia. Nat Rev Dis Primers. 2015;1:15022.

3. Oliveira Junior JO. Dor Oncológica. Acta Oncol Bras. 1994;14(1):11-5.

4. Skaer TL. Fibromyalgia: disease synopsis, medication cost effectiveness and economic burden. Pharmacoeconomics. 2014;32(5):457-66.

5. Podolecki T, Podolecki A, Hrycek A. Fibromyalgia: pathogenetic, diagnostic and therapeutic concerns. Pol Arch Med Wewn. 2009;119(3):157-61.

6. Gerardi MC, Batticciotto A, Talotta R, Di Franco M, Atzeni F, Sarzi-Puttini P. Novel pharmaceutical options for treating fibromyalgia. Expert Rev Clin Pharmacol. 2016:1-7.

7. Kia S, Choy E. Update on Treatment Guideline in Fibromyalgia Syndrome with Focus on Pharmacology. Biomedicines. 2017;5(2):20.

8. Fitzcharles MA, Ste-Marie PA, Goldenberg DL, Pereira JX, Abbey S, Choiniere M, et al. 2012 Canadian Guidelines for the diagnosis and management of fibromyalgia syndrome: executive summary. Pain Res Manag. 2013;18(3):119-26.

9. Bennett RM, Gatter RA, Campbell SM, Andrews RP, Clark SR, Scarola JA. A comparison of cyclobenzaprine and placebo in the management of fibrositis. A double-blind controlled study. Arthritis Rheum. 1988;31(12):1535-42.

10. Tofferi JK, Jackson JL, O’Malley PG. Treatment of fibromyalgia with cyclobenzaprine: a meta-analysis. Arthritis Rheum. 2004;51(1):9-13.

11. Macfarlane GJ, Kronisch C, Dean LE, Atzeni F, Hauser W, Fluss E, et al. EULAR revised recommendations for the management of fibromyalgia. Ann Rheum Dis. 2017;76(2):318-28.

12. Lunn MP, Hughes RA, Wiffen PJ. Duloxetine for treating painful neuropathy, chronic pain or fibromyalgia. Cochrane Database Syst Rev. 2014(1):CD007115.

13. Walitt B, Urrutia G, Nishishinya MB, Cantrell SE, Hauser W. Selective serotonin reuptake inhibitors for fibromyalgia syndrome. Cochrane Database Syst Rev. 2015(6):CD011735

14. Carville SF, Arendt-Nielsen L, Bliddal H, Blotman F, Branco JC, Buskila D, et al EULAR evidence-based recommendations for the management of fibromyalgia syndrome. Ann Rheum Dis. 2008;67(4):536-41.

15. Arnold LM, Clauw DJ, Wohlreich MM, Wang F, Ahl J, Gaynor PJ, et al. Efficacy of duloxetine in patients with fibromyalgia: pooled analysis of 4 placebo-controlled clinical trials. Prim Care Companion J Clin Psychiatry. 2009;11(5):237-44.

16. Arnold LM, Gendreau RM, Palmer RH, Gendreau JF, Wang Y. Efficacy and safety of milnacipran $100 \mathrm{mg} /$ day in patients with fibromyalgia: results of a randomized, double-blind, placebo-controlled trial. Arthritis Rheum. 2010;62(9):2745-56.

17. Arnold LM, Wang F, Ahl J, Gaynor PJ, Wohlreich MM. Improvement in multiple dimensions of fatigue in patients with fibromyalgia treated with duloxetine: secondary analysis of a randomized, placebo-controlled trial. Arthritis Res Ther. 2011;13(3):R86.

18. Clauw DJ, Mease P, Palmer RH, Gendreau RM, Wang Y. Milnacipran for the treatment of fibromyalgia in adults: a 15-week, multicenter, randomized, double-blind, placebo-controlled, multiple-dose clinical trial. Clin Ther. 2008;30(11):1988-2004.

19. Mease PJ, Clauw DJ, Gendreau RM, Rao SG, Kranzler J, Chen W, et al. The efficacy and safety of milnacipran for treatment of fibromyalgia. a randomized, double-blind, placebo-controlled trial. J Rheumatol. 2009;36(2):398-409.

20. Vaishnavi SN, Nemeroff CB, Plott SJ, Rao SG, Kranzler J, Owens MJ. Milnacipran: a comparative analysis of human monoamine uptake and transporter binding affinity. Biol Psychiatry. 2004;55(3):320-2.

21. Cymbalta (duloxetine hydrochloride). Prescribing information. Indianapolis: Eli Lily and Company; 2014.

22. Savella (milnacipran hydrochloride). Prescribing Information. New York: Forest La- 
boratories, Inc.; 2013

23. Arnold LM, Choy E, Clauw DJ, Oka H, Whalen E, Semel D, et al. An evidence-based review of pregabalin for the treatment of fibromyalgia. Curr Med Res Opin. 2018:113.

24. Tzellos TG, Toulis KA, Goulis DG, Papazisis G, Zampeli VA, Vakfari A, et al. Gabapentin and pregabalin in the treatment of fibromyalgia: a systematic review and a meta-analysis. J Clin Pharm Ther. 2010;35(6):639-56.

25. Derry S, Cording M, Wiffen PJ, Law S, Phillips T, Moore RA. Pregabalin for pain in fibromyalgia in adults. Cochrane Database Syst Res. 2017;9:CD011790.

26. Fink K, Dooley DJ, Meder WP, Suman-Chauhan N, Duffy S, Clusmann H, et al. Inhibition of neuronal $\mathrm{Ca}(2+)$ influx by gabapentin and pregabalin in the human neocortex. Neuropharmacology. 2002;42(2):229-36.

27. Cooper TE, Derry S, Wiffen PJ, Moore RA. Gabapentin for fibromyalgia pain in adults. Cochrane Database Syst Rev. 2017;1:CD012188.

28. Busch JA, Pregabalin (CI-1008) multiple-dose pharmacokinetics and safety/tolerance in healthy volunteers. Pharm Sci. 1999;1(Suppl 4):2033.

29. Baidya DK, Agarwal A, Khanna P, Arora MK. Pregabalin in acute and chronic pain. J Anaesthesiol Clin Pharmacol. 2011;27(3):307-14.

30. Bockbrader HN. Pregabalin pharmacokinetics and safety in healthy volunteers: results from two phase 1 studies. Neurology. 2000;54(Suppl 3):421.

31. Su TZ, Feng MR, Weber ML. Mediation of highly concentrative uptake of pregabalin by L-type amino acid transport in Chinese hamster ovary and Caco-2 cells. J Pharmacol Exp Ther. 2005;313(3):1406-15.

32. Freynhagen R, Strojek K, Griesing T, Whalen E, Balkenohl M. Efficacy of pregabalin in neuropathic pain evaluated in a 12-week, randomised, double-blind, multicentre, placebo-controlled trial of flexible- and fixed-dose regimens. Pain. 2005;115(3):254-63.

33. Bryans JS, Wustrow DJ. 3-substituted GABA analogs with central nervous system activity: a review. Med Res Rev. 1999;19(2):149-77.

34. Lauria-Horner BA, Pohl RB. Pregabalin: a new anxiolytic. Expert Opin Investig Drugs. 2003;12(4):663-72.

35. Boomershine CS. Pregabalin for the management of fibromyalgia syndrome. J Pain Res. 2010;3:81-8.

36. Harris RE, Clauw DJ, Scott DJ, McLean SA, Gracely RH, Zubieta JK. Decreased central mu-opioid receptor availability in fibromyalgia. J Neurosci. 2007;27(37):10000-6.

37. Baraniuk JN, Whalen G, Cunningham J, Clauw DJ. Cerebrospinal fluid levels of opioid peptides in fibromyalgia and chronic low back pain. BMC Musculoskelet Disord. 2004:5:48

38. 28. Lawson K. Emerging pharmacological strategies for the treatment of fibromyalgia. World J Pharmacology. 2017;6(1):1-10.

39. Sluka KA, Clauw DJ. Neurobiology of fibromyalgia and chronic widespread pain. Neuroscience. 2016;338:114-29.

40. Younger J, Noor N, McCue R, Mackey S. Low-dose naltrexone for the treatment of fibromyalgia: findings of a small, randomized, double-blind, placebo-controlled, counterbalanced, crossover trial assessing daily pain levels. Arthritis Rheum. 2013;65(2):529-38.

41. Tsuda M, Masuda T, Tozaki-Saitoh H, Inoue K. Microglial regulation of neuropathic pain. J Pharmacol Sci. 2013;121(2):89-94.

42. Ngian GS, Guymer EK, Littlejohn GO. The use of opioids in fibromyalgia. Int J Rheum Dis. 2011;14(1):6-11.

43. Derry S, Wiffen PJ, Hauser W, Mucke M, Tolle TR, Bell RF, et al. Oral nonsteroidal anti-inflammatory drugs for fibromyalgia in adults. Cochrane Database Syst Rev. 2017;3:CD012332.

44. Gould GG, Seillier A, Weiss G, Giuffrida A, Burke TF, Hensler JG, et al. Acetaminophen differentially enhances social behavior and cortical cannabinoid levels in inbred mice. Prog Neuropsychopharmacol Biol Psychiatry. 2012;38(2):260-9.

45. Weber J, Schley M, Casutt M, Gerber H, Schuepfer G, Rukwied R, et al. Tetrahydrocannabinol (Delta 9-THC) treatment in chronic central neuropathic pain and fibromyalgia patients: results of a multicenter survey. Anesthesiol Res Pract. 2009;2009: pii: 827290 .

46. Skrabek RQ, Galimova L, Ethans K, Perry D. Nabilone for the treatment of pain in fibromyalgia. J Pain. 2008;9(2):164-73.

47. Ware MA, Fitzcharles MA, Joseph L, Shir Y. The effects of nabilone on sleep in fibromyalgia: results of a randomized controlled trial. Anesth Analg. 2010;110(2):60410.

48. THC Pro-Drug Patch - ZYN001. Being Studied in Fibromyalgia and Peripheral Neuropathic Pain. Zynerba Pharmaceuticals, Inc. [Available from: http://zynerba.com/ in-development/thc-prodrug-patch-zyn001/.

49. Banks S, O'Neill C, Sebreee T. Pharmacokinetic Evaluation of Subcutaneously Administered ZYN001 in Male Sprague-Dawley Rats. [Available from: http://zynerba.com/ publications.

50. Walitt B, Klose P, Fitzcharles MA, Phillips T, Hauser W. Cannabinoids for fibromyalgia. Cochrane Database Syst Rev. 2016;7:CD011694.

51. Tafelski S, Hauser W, Schafer M. Efficacy, tolerability, and safety of cannabinoids for chemotherapy-induced nausea and vomiting--a systematic review of systematic reviews. Schmerz. 2016;30(1):14-24.

52. Farré M, Farré A, Fiz J, Torrens M. Cannabis Use in fibromyalgia. Handbook of Cannabis and Related Pathologies. 2017. 158-67p.

53. Lawson K. Potential drug therapies for the treatment of fibromyalgia. Expert Opin Investig Drugs. 2016;25(9):1071-81.

54. Schumacher M, Pasvankas G. Topical capsaicin formulations in the management of neuropathic pain. Prog Drug Res. 2014;68:105-28.

55. Oliveira Junior J. Efeito analgésico periférico do tramadol em modelo de dor pós-operatória em ratos: Universidade de Sáo Paulo; 2015.

56. Casanueva B, Rodero B, Quintial C, Llorca J, Gonzalez-Gay MA. Short-term efficacy of topical capsaicin therapy in severely affected fibromyalgia patients. Rheumatol Int. 2013;33(10):2665-70

57. Zhou HY, Chen SR, Pan HL. Targeting N-methyl-D-aspartate receptors for treat ment of neuropathic pain. Expert Rev Clin Pharmacol. 2011;4(3):379-88.

58. Foerster BR, Nascimento TD, DeBoer M, Bender MA, Rice IC, Truong DQ, et al Excitatory and inhibitory brain metabolites as targets of motor cortex transcranial direct current stimulation therapy and predictors of its efficacy in fibromyalgia. Arthritis Rheumatol. 2015;67(2):576-81.

59. Harte SE, Clauw DJ, Napadow V, Harris RE. Pressure pain sensitivity and insular combined glutamate and glutamine (Glx) are associated with subsequent clinical response to sham but not traditional acupuncture in patients who have chronic pain. Med Acupunct. 2013;25(2):154-60.

60. Fayed N, Olivan-Blazquez B, Herrera-Mercadal P, Puebla-Guedea M, Perez-Yus MC, Andres $\mathrm{E}$, et al. Changes in metabolites after treatment with memantine in fibromyalgia. A double-blind randomized controlled trial with magnetic resonance spectroscopy with a 6-month follow-up. CNS Neurosci Ther. 2014;20(11):999-1007.

61. Lu KW, Hsieh CL, Yang J, Lin YW. Effects of electroacupuncture in a mouse model of fibromyalgia: role of $\mathrm{N}$-methyl-D-aspartate receptors and related mechanisms. Acupunct Med. 2017;35(1):59-68.

62. Harris RE, Napadow V, Huggins JP, Pauer L, Kim J, Hampson J, et al. Pregabalin rectifies aberrant brain chemistry, connectivity, and functional response in chronic pain patients. Anesthesiology. 2013;119(6):1453-64.

63. Srinivasan V, Pandi-Perumal SR, Spence DW, Moscovitch A, Trakht I, Brown GM, et al. Potential use of melatonergic drugs in analgesia: mechanisms of action. Brain Res Bull. 2010;81(4-5):362-71.

64. de Zanette SA, Vercelino R, Laste G, Rozisky JR, Schwertner A, Machado CB, et al. Melatonin analgesia is associated with improvement of the descending endogenous pain-modulating system in fibromyalgia: a phase II, randomized, double-dummy, controlled trial. BMC Pharmacol Toxicol. 2014;15:40.

65. Hussain SA, Al K, II, Jasim NA, Gorial FI. Adjuvant use of melatonin for treatment of fibromyalgia. J Pineal Res. 2011;50(3):267-71.

66. Bruno A, Mico U, Lorusso S, Cogliandro N, Pandolfo G, Caminiti M, et al. Agomelatine in the treatment of fibromyalgia: a 12-week, open-label, uncontrolled preliminary study. J Clin Psychopharmacol. 2013;33(4):507-11.

67. Calandre EP, Slim M, Garcia-Leiva JM, Rodriguez-Lopez CM, Torres P, Rico-Villademoros F. Agomelatine for the treatment of patients with fibromyalgia and depressive symptomatology: an uncontrolled, 12-week, pilot study. Pharmacopsychiatry. 2014;47(2):67-72.

68. Turk DC, Adams LM. Using a biopsychosocial perspective in the treatment of fibromyalgia patients. Pain Manag. 2016;6(4):357-69.

69. Deare JC, Zheng Z, Xue CC, Liu JP, Shang J, Scott SW, et al. Acupuncture for treating fibromyalgia. Cochrane Database Syst Rev. 2013(5):CD007070.

70. Burnstock G. Purinergic nerves. Pharmacol Rev. 1972;24(3):509-81

71. Burnstock G. Physiology and pathophysiology of purinergic neurotransmission. Physiol Rev. 2007;87(2):659-797.

72. Burnstock G. Acupuncture: a novel hypothesis for the involvement of purinergic signaling. Med Hypotheses. 2009;73(4):470-2.

73. Tang Y, Yin HY, Rubini P, Illes P. Acupuncture-induced analgesia: a neurobiological basis in purinergic signaling. Neuroscientist. 2016;22(6):563-78.

74. Nedergaard M. Enhancing the therapeutic effect of acupuncture with adenosine US2013.

75. Takano T, Chen X, Luo F, Fujita T, Ren Z, Goldman N, et al. Traditional acupuncture triggers a local increase in adenosine in human subjects. J Pain. 2012;13(12):1215-23.

76. Perissinoti D, editor $8^{\text {th }}$ Annual Meeting of Biofeedback Foundation European (BFE). $2^{\text {nd }}$ Annual Meetingof International Society for Neuronal (E-isnr). $8^{\text {th }}$ Annual Meeting of Biofeedback Foundation European (BFE) $2^{\text {nd }}$ Annual Meetingof International Society for Neuronal (E-isnr); Psicologia Hospitalar, 2004.

77. Theadom A, Cropley M, Smith HE, Feigin VL, McPherson K. Mind and body therapy for fibromyalgia. Cochrane Database Syst Rev. 2015(4):CD001980.

78. Bernardy K, Klose P, Busch AJ, Choy EH, Hauser W. Cognitive behavioural therapies for fibromyalgia. Cochrane Database Syst Rev. 2013(9):CD009796.

79. Fordyce WE. Behavioral Concepts in Chronic Pain and Illness. St. Louis, MO, USA: Mosby; 1976.

80. Thieme K, Gromnica-Ihle E, Flor H. Operant behavioral treatment of fibromyalgia: a controlled study. Arthritis Rheum. 2003;49(3):314-20.

81. Thieme K, Flor H, Turk DC. Psychological pain treatment in fibromyalgia syndrome: efficacy of operant behavioural and cognitive behavioural treatments. Arthritis Res Ther. 2006;8(4):R121.

82. Diers M, Yilmaz P, Rance M, Thieme K, Gracely RH, Rolko C, et al. Treatment-related changes in brain activation in patients with fibromyalgia syndrome. Exp Brain Res. 2012;218(4):619-28.

83. Hassett AL, Williams DA. Non-pharmacological treatment of chronic widespread musculoskeletal pain. Best Pract Res Clin Rheumatol. 2011;25(2):299-309.

84. Hoffman BM, Papas RK, Chatkoff DK, Kerns RD. Meta-analysis of psychological interventions for chronic low back pain. Health Psychol. 2007;26(1):1-9.

85. Jensen KB, Kosek E, Wicksell R, Kemani M, Olsson G, Merle JV, et al. Cognitive Behavioral Therapy increases pain-evoked activation of the prefrontal cortex in pa- 
tients with fibromyalgia. Pain. 2012;153(7):1495-503.

86. Frith C, Dolan RJ. Brain mechanisms associated with top-down processes in perception. Philos Trans R Soc Lond B Biol Sci. 1997;352(1358):1221-30.

87. Williams DA, Clauw DJ. Understanding fibromyalgia: lessons from the broader pain research community. J Pain. 2009;10(8):777-91.

88. Busch AJ, Webber SC, Brachaniec M, Bidonde J, Bello-Haas VD, Danyliw AD, et al. Exercise therapy for fibromyalgia. Curr Pain Headache Rep. 2011;15(5):358-67.

89. Naumann J, Sadaghiani C. Therapeutic benefit of balneotherapy and hydrotherapy in the management of fibromyalgia syndrome: a qualitative systematic review and meta-analysis of randomized controlled trials. Arthritis Res Ther. 2014;16(4):R141.

90. Efrati S, Fishlev G, Bechor Y, Volkov O, Bergan J, Kliakhandler K, et al. Hyperbaric oxygen induces late neuroplasticity in post stroke patients--randomized, prospective trial. PLoS One. 2013;8(1):e53716.

91. Sutherland AM, Clarke HA, Katz J, Katznelson R. Hyperbaric oxygen therapy: a new treatment for chronic pain? Pain Pract. 2016;16(5):620-8.

92. Rokitansky O. Clinical consideration and biochemistry of ozone therapy. Hospitalis. 1982;52:643-711.

93. Hidalgo-Tallon J, Menendez-Cepero S, Vilchez JS, Rodriguez-Lopez CM, Calandre EP. Ozone therapy as add-on treatment in fibromyalgia management by rectal insu- fflation: an open-label pilot study. J Altern Complement Med. 2013;19(3):238-42.

94. Wu X, Li Z, Liu X, Peng H, Huang Y, Luo G, et al. Major ozonated autohemotherapy promotes the recovery of upper limb motor function in patients with acute cerebral infarction. Neural Regen Res. 2013;8(5):461-8.

95. Borrelli E, Bocci V. A novel therapeutic option for chronic fatigue syndrome and fibromyalgia. Rivista Italiana di Ossigeno-Ozonoterapia. 2002;1:149-53.

96. Efrati S, Golan H, Bechor Y, Faran Y, Daphna-Tekoah S, Sekler G, et al. Hyperbaric oxygen therapy can diminish fibromyalgia syndrome--prospective clinical trial. PLoS One. 2015;10(5):e0127012.

97. Hou WH, Wang TY, Kang JH. The effects of add-on non-invasive brain stimulation in fibromyalgia: a meta-analysis and meta-regression of randomized controlled trials. Rheumatology (Oxford). 2016;55(8):1507-17.

98. Saltychev M, Laimi K. Effectiveness of repetitive transcranial magnetic stimulation in patients with fibromyalgia: a meta-analysis. Int J Rehabil Res. 2017;40(1):11-8.

99. Ablin JN, Amital H, Ehrenfeld M, Aloush V, Elkayam O, Langevitz P, et al. [Guidelines for the diagnosis and treatment of the fibromyalgia syndrome]. Harefuah. 2013;152(12):742-7.

100. Oliveira Jr JO, Andrade MP, Carrocini D. Poster. Abstracts of the $8^{\text {th }}$ World Congress on Pain, August 17-22, Vancouver: IASP; 1996. 